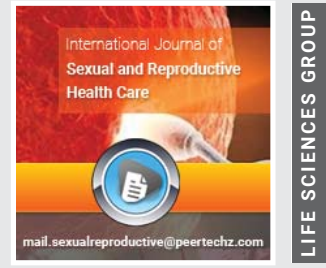

\title{
Assessment of sexuality in patients with Peyronie's disease
}

\author{
Moussaab Rachid*, Gallouo M, Graiouid M, Allali S, Seffar A, \\ Dakir M, Debbagh A and Aboutaieb R
}

Medical Doctor, Sexual Health Laboratory, Hassan 2 University Casablanca, Morocco

Received: 29 January, 2020

Accepted: 04 March, 2020

Published: 05 March, 2020

*Corresponding author: Moussaab Rachid, Medical Doctor, Sexual Health Laboratory, Hassan 2 University Casablanca, Morocco, Tel: 212645108374;

E-mail:moussaaburo@gmail.com

Keywords: Erectile dysfunction; Quality of life; Peyronie's disease

https://www.peertechz.com

\section{Check for updates}

\begin{abstract}
Introduction: Peyronie's disease is an acquired fibrosis of the corpora cavernosa which causes deformation of the penis and represents one of the causes of erectile insufficiency with serious consequences for the life of a couple. The diagnosis is clinical and the treatment is medico-surgical.

Objective: Evaluation of the sexuality of patients with Peyronie's disease.

Patients and methods: This prospective study occured from February 2017 to December 2019 including patients suffering all from Peyronie's Disease (PD). The IIEF (International Index of Erectile Function), EHS (Erection Hardness Score) and T LUE scores were used to assess erectile function and the severity of PD. The preestablished data were: Age, co-morbidities, delays, medical background, the onset mode, data from the penis examination in the flaccid state and in erection, general examination and therapeutic management.
\end{abstract}

Results: We listed 20 patients; the average age is 58.2 years (39-69years). The onset was progressive in $80 \%$ of the patients; the average consultation time was 14.1 months. Deformation was the most frequent symptom in $70 \%$ of cases, followed by the coital discomfort in $50 \%$. Intromission was accompanied by a discomfort in $60 \%$. In $80 \%$ of patients the disease was at the sclerotic stage. Palpation of the plaque was found in $60 \%$ of patients. The IIEF score was 14,6 and $80 \%$ of patients had erectile dysfunction, $40 \%$ of which was moderate. Grade 4 EHS was predominant in $60 \%$, pain was mild in erection in $40 \%$ case. Dyspareunia has been reported by $60 \%$ of partners. Medical treatment was prescribed for $60 \%$ of our patients, $40 \%$ of whom received medical treatment for the dysfunction.

Conclusions: PD significantly alters the sexual and relational quality of patient's lives.

\section{Introduction}

Erectile dysfunction is the most common sexual disorder reported by men, which is defined by the persistent or recurrent inability to obtain or maintain an erection allowing satisfactory sexual intercourse [1]. It represents a clinical marker of overall health and quality of a man's life. Peyronie's disease which is an acquired fibrosis of the corpora cavernosa which causes deformation of the penis, represents one of the causes of severe erectile insufficiency in advanced forms with loss of selfesteem, devaluation, deprivation of harmony and dynamics of the couple and the family. The psycho-social consequences of Peyronie's disease justifies a prospective descriptive study whose aim is to assess the sexuality of patients with PD.

\section{Patients and methods}

We carried out a prospective study from February 2017 to December 2019 reporting patients consulting at the urology department of the University hospital center Ibn Rochd in Morocco. Were included in our study all male patients meeting the criteria of the definition: deformation of the penis, it's type of curvature, narrowing, strangulation and shortening with a plaque of fibrosis of the corpora cavernosa. Were excluded all patients having a bend of the penis without fibrous plate. The exploitation of the files was done using a counting sheet, the size of our sample was 20 .

\section{The data collected were:}

- Clinics: Age, background, profession, mode of occurrence. 
- Data from the examination of the penis in a flaccid state and in erections and the general examination.

- Therapeutic data: We used the IIFF SCORE to assess erectile function. This is a score that assesses erectile function for 6 months, it contains 5 ITEMS grouped into 5 questions rated from 1 to 5 . For its interpretation: score 5 to 10 , the erection disorder is qualified severe, score 11 to 15 moderate, while score 16 to 20 is judged light. The quality of the erection will be assessed by the EHS score. It is a tool for measuring erectile function which includes 4 grades. The severity of the disease will be assessed by the T LUE score. Patients who were invited to participate in the study received the relevant indications and signed informed consent and were contacted by phone.

The questionnaire and the scores were filled in French either by:

- The doctor whose mother tongue was Arabic for patients with low education needing translation.

- The patient with a high level of education but in the presence of the doctor.

\section{Results}

Average age is about 58.2years (39-69years) the most represented average age group is 30 to 40 followed by 50-60.

Diabetes and hypertension were present respectively in $20 \%$ of cases. Only one patient reported a trauma to the penis. $20 \%$ of patients had undergone urological surgery, $80 \%$ of them it was an inguinal hernia repair. The onset was progressive in $80 \%$ of patients, and the average consultation time was 14.1 months (15days to 02years). Deformation was the most frequent symptom in $70 \%$ of cases followed by the coital gene in $50 \%$ [2]

Intromission was impossible in all our patients; it was accompanied by a gene in $60 \%$. Premature ejaculation occurred in one patient and $80 \%$ of patients consulted at the sclerotic stage of the disease. All patients had a penis deformation during erection caused by the injection of "prostaglandin E2" , $80 \%$ of which had a non-complex figure curvature (Figure 1) and in $20 \%$ it was a complex (Figure 2 ).

Palpation of the plaque was found in $60 \%$ of patients. The general examination was normal in all patients. In $80 \%$ of cases, the patients suffered from erectile dysfunction and moderate erectile dysfunction in $40 \%$ of cases, followed by severe dysfunction in $30 \%$ of cases. Grade 4 was predominant in $60 \%$ followed by grades 1 and 2 . The average score was 4.1, pain was mild at erection in $40 \%$, and mild at coitus in $20 \%$. In $60 \%$ the degree of curvature was $15^{\circ}$. Half of our patients had a $1 \mathrm{~cm}$ plate and $10 \%$ was $2 \mathrm{~cm}$. Dyspareunia was reported by $60 \%$ of partners. Medical treatment was prescribed in $60 \%$ of our patients, $40 \%$ of them received medical treatment for erectile dysfunction. Resumption of normal sexual activity noted in all treated patients.

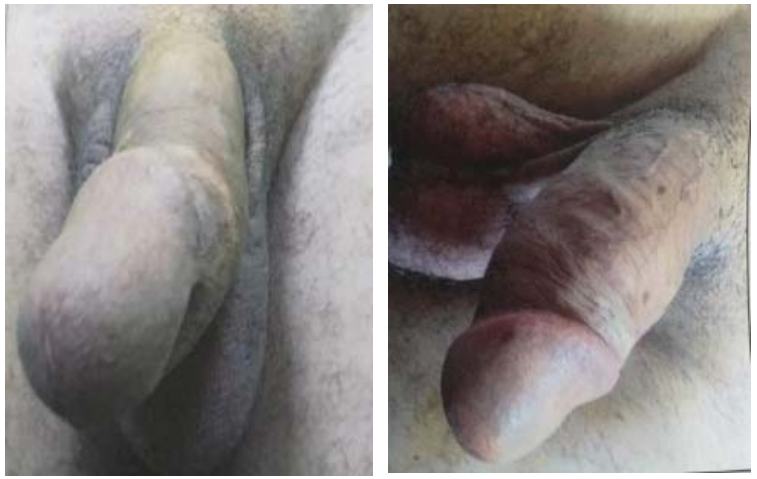

Figure 1: Dorso-lateral curvature of the penis (a), lateral curvature of the penis (b)

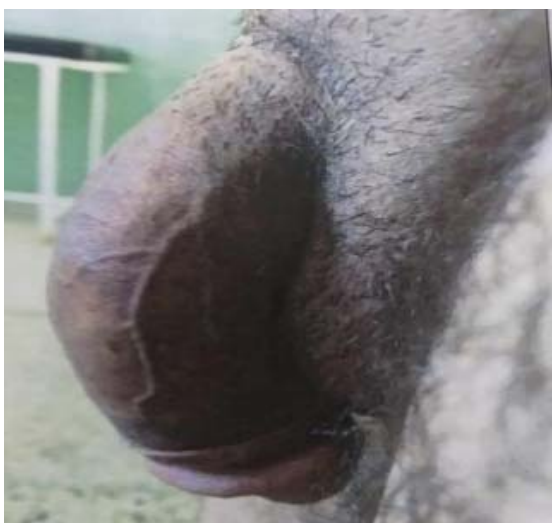

Figure 2: Ventral curve of the penis.

\section{Discussion}

The prevalence of Peyronie's disease is a challenge, it varies from 0.3 to $13 \%$ depending on age, geographic location, co-morbidities and socioeconomic status [1-4]. the average age varies between 48, 9 and 57.4 years [5-7]. This later was slightly higher in our study (about 58.2years) compared to the literature data and the most represented age group is that of 30 to 40 . The insidious onset in $80 \%$ of patients, and the average delay of consultation late at $\mathbf{1 4 . 1}$ months would explain this. The taboo nature of the disease and the ignorance of this affection might also explain the delay in treatment. Epidemiological studies have objectified the association of PD and cardiovascular risk factors such as diabetes, hypertension, dyslipidemia, chronic smoking $[8,9]$. This is how Carlo and $\mathrm{Al}$ [10], in Italy in 2015 found diabetes to have $21 \%$ frequency, $57 \%$ hypertension and Tobacco $64 \%$. Shiaraishi and Japan [11], reported diabetes, hypertension and tobacco respectively in $32.5 \%, 58 \%$ and $24 \%$. The pathophysiology of this condition is poorly understood and multifactorial [12-14].

* Traumatic factors: Internal iterative microtrauma following prolonged erection and external following penetration difficulties, one in ten of our patients had reported trauma by direct kick on the penis.

* Genetic and hereditary factors.

* Immune factors.

* Metabolic factor 
The diagnosis of PD is clinical and is described in two phases [15,16]:

- An early one: Inflammatory where the patient presents a penis nodule, a painful erection or a deformation.

- A delate one: The nodule perceived very hard, the deformation is stable, the pain has most often disappeared and sometimes the erectile dysfunction too.

The clinical examination is done in a flaccid state and in erection, it allows to palpate and locate the nodule it appreciates the degree of curvature on the three space planes. Deformation was the most frequent symptom in our study in $70 \%$ in the flaccid state and $100 \%$ in the erection caused by the injection of the "Prostaglandin E2", 80\% of which had a non-complex curvature, these data are similar to those in the literature where the curvature varies from 65 to $100 \%[17,18]$. The deformation occurs next to the fibrous plaque or nodule [19]. The intensity and severity of this pain varies depending on the duration of the disease, the extent of the alteration of the penile shape and different positions around sexual intercourse [20]. Erection or coitus pain can reveal the disease, its intensity varies from a simple discomfort to permanent pain even in a flaccid state, in our study the frequency was $50 \%$. This corroborates with data from other studies where the pain varies $33 \%-72 \%[4,21,22]$. Penile induration is found in patients who consult only in the late phase where the curvature is manifest (Paraclinical examinations have no place in the diagnosis, the clinic is sufficient). However, ultrasound can visualize a hyperechoic plaque of the albuginea, specify their number, location and size, but the intra-cavernous doppler makes it possible to carry out the vascular assessment of erectile dysfunction [23]. MRI gives more precision on the plaque, appreciates better the nonpalpable cavernous bodies, the enhancement after injection of gadolinium reflects possible inflammation, the interest lies in the therapeutic choice. Peyronie's disease is often associated with erectile dysfunction [24].

The penetration capacity can be interfered by the curvature or the deformation resulting in erectile dysfunction [17]. This is how Rodrigeuez V, et al., [25], objectified a rate of $65 \%$ suffering from erectile dysfunction due to a difficult or impossible penetration. Walsh, et al., [26], reported $36.8 \%$ of sexual dysfunction related to curvature and shortening. Dysfunction was found in $80 \%$ of our patients. Pain and curvature in more than half of our patients would explain this erectile insufficiency. The treatment of PD includes both medical and surgical approaches. Different therapeutic options available to the patient include monitoring, topical or intralesional medication, mechanical therapy, and surgery [27], which is reserved for sequels of the inflammation phase. The limitations of this study are mainly related to its retrospective nature. We must therefore deplore a certain number missing data as well as the follow-up of certain patients who were lost to see.

\section{Conclusion}

Peyronie's disease seems to seriously affect the quality of life of patients, particularly in its sexual component. These sexual disorders can be linked on one hand to the affection itself and the anxiety created by its symptoms and on the other hand to the patient by cardiovascular risk factors.

\section{References}

1. DiBenedetti DB, Nguyen D, Zografos L, Ziemieck R, Zhou X (2011) A PopulationBased Study of Peyronie's Disease: Prevalence and Treatment Patterns in the United States. Adv Urol 1-9. Link: http://bit.ly/2x4zH5U

2. El-Sakka Al (2006) Prevalence of Peyronie's Disease Among Patients With Erectile Dysfunction. Eur Urol 49: 564-569. Link: http://bit.ly/2vlk2c6

3. Sommer F, Schwarzer U, Wassmer G, Bloch W, Braun M, et al. (2002) Epidemiology of Peyronie's disease. Int $\mathrm{J}$ Impot Res 379-383. Link: https://go.nature.com/2TGtrsK

4. Lindsay MB, Schain DM, Grambsch P, Benson RC, Beard CM (1991) The Incidence of Peyronie's Disease in Rochester, Minnesota, 1950 through 1984. J Urology 1007-1009. Link: http://bit.ly/2uTqJI0

5. Ashworth A (1960) Peyronie's Disease. Journal Royal Society of Medicine 692-694. Link: http://bit.ly/3as5GeQ

6. Desanctis PN, Furey CA (1967) Steroid Injection Therapy for Peyronie's Disease: A 10-Year Summary and Review of 38 Cases. J Urol 114-116. Link: http://bit.ly/2vtU10l

7. Frank IN, Scott WW (1971) The Ultrasonic Treatment of Peyronie's Disease. J Urol 883-887. Link: http://bit.ly/2lhs5zo

8. Mulhall JP, Creech SD, Boorjian SA, Ghaly S, Kim ED, et al. (2004) Subjective and objective analysis of the prevalence of Peyronie's disease in a population of men presenting for prostate cancer screening. J Urol 171: 2350-2353. Link: http://bit.ly/2wrt11F

9. Arafa M, Eid H, El-Badry A, Ezz-Eldine K, Shamlou R (2007) The prevalence of Peyronie's disease in diabetic patients with erectile dysfunction. Int $\mathrm{J}$ Impot Res 19: 213-217. Link: https://go.nature.com/2POfCHQ

10. Pavone C, D'Amato F, Dispensa N, Torretta F, Magno C (2015) Smoking diabetes, blood hypertension: possible etiologic role for Peyronie's disease? Analysis in 279 patients with a control group in Sicily. Arch Ital Urol Androl 87 20-24. Link: http://bit.ly/2PPGUNN

11. Deveci S, Hopps CV, O'Brien K, Parker M, Guhring P, et al. (2007) Defining the Clinical Characteristics of Peyronie's Disease in Young Men. J Sex Med 485-490. Link: http://bit.ly/38s7CCy

12. Wesson MB (1943) Peyronie's Disease (Plastic Induration), Cause and Treatment 11 Read at the twentieth annual meeting of the Western Section, American Urological Association, at Del Monte, Calif June 22-24, 1942 and at the Nevada State Medical Society Sept 26-27 1942. J Urol 49: 350-356.

13. Craig JR, Brant WO, Smith JF, Lue TF (2016) Peyronie's Disease: Natural History, Diagnosis, and Medical Therapy. In Contemporary Treatment of Erectile Dysfunction. TS Köhler, KT McVary Éd. Cham. :Springer International Publishing 289-300. Link: http://bit.ly/2PNH2x8

14. Somers KD, Winters BA, Dawson DM, Leffell MS, Wright GL, et al. (1987) Chromosome Abnormalities in Peyronie's Disease. J Urol 137: 672-675. Link: http://bit.ly/32PYcjj

15. Al-Thakaf S, Al-Hathai N (2016) Peyronie's disease: a literature review on epidemiology, genetics, pathophysiology, diagnosis and work-up. Trans Androl Urol 5: 280-289. Link: http://bit.ly/2Imqto0

16. Grasso M, Lania C, Blanco S, Limonta G (2007) The natural history of Peyronie's disease. Urol 60: 326-331. Link: http://bit.ly/2VNOOLE

17. Bondi P, Salti RS, Bouguetaia A, Aladawi F, Sabbagh R (1998) Maladie de La Peyronie: La clinique a-t-elle encore un interet? . Andrologie 8: 138-147. Link: http://bit.ly/32RWTQF

Citation: Rachid M, Gallouo M, Graiouid M, Allali S, Seffar A, et al. (2020) Assessment of sexuality in patients with Peyronie's disease. Int J Sex Reprod Health Care 
18. Mulhall JP, Schiff J, Guhring P (2006) An Analysis of the Natural History of Peyronie's Disease. J Urol 175: 2115-2118. Link: http://bit.ly/2VKYwy9

19. Garcia-Gomez B, Ralph D, Levine L, Moncada-Iribarren I, Djinovic R, et al. (2018) Grafts for Peyronie's disease: a comprehensive review. Andrology 6 : 117-126. Link: http://bit.ly/2PNSoS0

20. Tal R, Hall MS, Alex B, Choi J, Mulhall JP (2012) Peyronie's Disease in Teenagers. J Sex Med 9: 302-308. Link: http://bit.ly/2THhSkW

21. Bondil P, Salti R, Bouguetaia A, Aladawi F, Sabbagh R (1998) Maladie de La Peyronie: La clinique a-t-elle encore un interet? Andrologie 8: 138-147. Link: http://bit.ly/2PPg747

22. Furlow WL, Swenson HE, Lee RE (1975) Peyronie's Disease: A Study of its Natural History and Treatment with Orthovoltage Radiotherapy. J Urol 114: 69-71. Link: http://bit.ly/2VLDbo9

23. Kadioğlu A, Tefekli A, Ero H, Cayan S, Kandirali E (2000) Color Doppler ultrasound assessment of penile vascular system in men with Peyronie's diseasel. Int J Impot Res 12: 263-267. Link: https://go.nature.com/38pyva8

24. Alhammadi A, Ouzaid I, Fernandez P, Hupertan V, Ravery V (2018) The utility of MRI of the penis in the management of Peyronie disease. European Urology Supplements 17: e1311-e1312. Link: http://bit.ly/2uYALaY

25. Rodrigues $\mathrm{Cl}, \mathrm{Njo} \mathrm{KH}, \mathrm{ABMF}$ Karim ABMF (1995) Results of radiotherapy and vitamin $\mathrm{E}$ in the treatment of Peyronie's disease. Int $\mathrm{J}$ Radiat Oncol Biol Phys 31: 571-576. Link: http://bit.ly/38nUCOn

26. Walsh TJ, Hotaling JM, Lue TF, Smith JF (2013) How curved is too curved? The severity of penile deformity may predict sexual disability among men with Peyronie's disease. Int J Impot Res 25: 109-112. Link: https://go.nature. com/2PNfnN6

27. Bilgutay AN, Pastuszak AW (2015) Peyronie's Disease: A Review of Etiology, Diagnosis and Management. Curr Sex Health Rep 7: 117-131. Link: http://bit.ly/2lk48HL
Discover a bigger Impact and Visibility of your article publication with

\section{Peertechz Publications}

\section{Highlights}

* Signatory publisher of ORCID

- Signatory Publisher of DORA (San Francisco Declaration on Research Assessment)

- Articles archived in worlds' renowned service providers such as Portico, CNKI, AGRIS, TDNet, Base (Bielefeld University Library), CrossRef, Scilit, J-Gate etc.

* Journals indexed in ICMJE, SHERPA/ROMEO, Google Scholar etc.

* OAI-PMH (Open Archives Initiative Protocol for Metadata Harvesting)

* Dedicated Editorial Board for every journal

* Accurate and rapid peer-review process

* Increased citations of published articles through promotions

* Reduced timeline for article publication

Submit your articles and experience a new surge in publication services (https://www.peertechz.com/submission).

Peertechz journals wishes everlasting success in your every endeavours.

Copyright: @ 2020 Rachid M, et al. This is an open-access article distributed under the terms of the Creative Commons Attribution License, which permits unrestricted use distribution, and reproduction in any medium, provided the original author and source are credited.

Citation: Rachid M, Gallouo M, Graiouid M, Allali S, Seffar A, et al. (2020) Assessment of sexuality in patients with Peyronie's disease. Int J Sex Reprod Health Care 3(1): 001-004. DOI: https://dx.doi.org/10.17352/ijsrhc.000008 